\title{
Notes on the occurrence of Acetropis Fieber, 1858 (Hemiptera: Heteroptera: Miridae) in Poland, with a key to Polish species
}

\author{
Artur TASZAKOWSKI ${ }^{1}$ and Grzegorz GIERLASIŃSKI ${ }^{2}$ \\ ${ }^{1}$ Department of Zoology, Faculty of Biology and Environmental Protection, University of Silesia in Katowice, \\ Bankowa 9, 40-007 Katowice, Poland; artur.taszakowski@us.edu.pl (corresponding author) \\ 2Doliny Miętusiej 27/44, 43-316 Bielsko-Biała, Poland; ggierlas@gmail.com
}

\begin{abstract}
In Poland the genus Acetropis Fieber, 1858 is represented by three species: A. carinata (Herrich-Schaeffer, 1841), A. gimmerthalii (Flor, 1860) and A. longirostris Puton, 1875. The paper presents illustrated key for the identification of mentioned species, new localities in Poland and the range of their distribution in Palaearctic Region. Additional information on the biology of all species is provided.
\end{abstract}

Key words: true bugs, plant bugs, faunistics, new records, distribution, key to species

\section{INTRODUCTION}

The genus Acetropis Fieber, 1858 belongs to the family Miridae, the subfamily Mirinae and the tribe Stenodemini. Six species of this genus are known in Palaearctic, five of these represent the subgenus Acetropis, i.e. A. carinata (Herrich-Schaeffer, 1841), A. gimmerthalii (Flor, 1860), A. longirostris Puton, 1875, A. stysi Remane \& Günther, 2008 and A. sinuata Wagner, 1951, and a single one, namely A. atropis Reuter, 1895 - the subgenus Paracetropis (Remane \& Günther 2008, Aukema et al. 2013).

Representatives of the genus Acetropis are characterized by the elongated head with the frons distinctly elongated forward; the first segment of the antennae is thicker than the others. The lateral margins of pronotum are flattened and semierected. Sexual dimorphism occurs: males are always macropterous while females may be macropterous, or with wings reduced to various extent (most often referred to as pseudobrachypterous) (Wagner 1970); the sexes differ also in body colouration (Wagner \& Weber 1964).

These bugs occur in open habitats and feed on grasses (Poaceae) (Wachmann et al. 2004).

In the Polish fauna, the genus Acetropis is recently represented by three species (Fig. 1): A. carinata, A. gimmerthalii and A. longirostris (Gorczyca 2004, Lis \& Dubiel 2013).

\section{MATERIAL AND METHODS}

During the preparation of the manuscript we used the literature data, material deposited in collection of Department of Zoology, Faculty of Biology and Environmental Protection, University of Silesia in Katowice (DZUS) and their own observations.

The maps of the occurrence of insects in Poland were obtained by using software MapaUTM v5.2 (http://www.heteroptera.us.edu.pl/mapautm.html). The maps of occurrence in the Western Palaearctic are based on Catalogue of the Heteroptera of the Palaearctic Region (Kerzhner \& Josifov 1999, Aukema et al. 2013). The colour photographs were obtained by using the following equipment: Leica M205C (stereomicroscope), Leica DFC495 (camera), Leica application suite 4.9.0 (software), Panasonic Lumix DMC FZ-72 (camera), and free graphic editor Paint.NET 4.0.16. 
The borders of the geographical regions of Poland follow the Catalogue of the Polish Fauna (Burakowski et al. 1973).
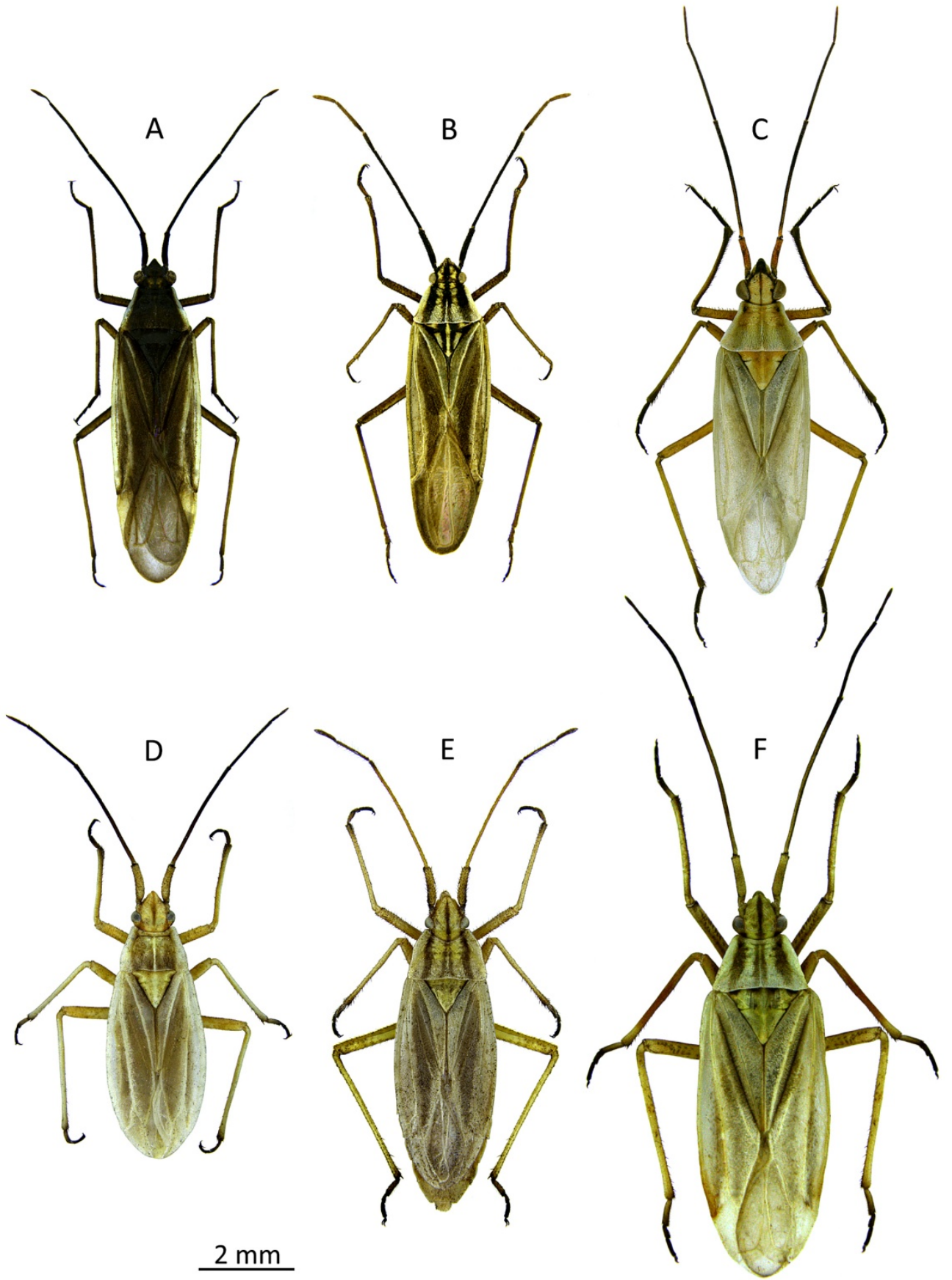

$\underline{2 \mathrm{~mm}}$

Fig 1. A-F: Habitus of the three Acetropis species. Upper row: males: A - A. carinata, B - A. gimmerthalii, C - A. longirostris. Bottom row: females: D - A. carinata, E - A. gimmerthalii, F - A. longirostris. Photo by A. Taszakowski. 


\section{SPECIES CHARACTERISTICS AND THEIR DISTRIBUTION}

\section{Acetropis carinata (Herrich-Schaeffer, 1841)}

Morphology. There is a distinct sexual dimorphism in the species (Fig. 1A, D). The male colouration is gray or almost black, vertex has two oblong spots, the middle line of scutellum, exocorium, cuneus and veins of corium are yellow. Legs are yellow-gray, tarsi and antennae are black. Female colouration is whitish or brownish-yellow. Head has three, pronotum and scutellum two oblong brown stripes. First and base of second antennae segment yellowish, the remaining segments black. Carinae of forewings with brown lines. Female most commonly pseudobrachypterous. Carina of pronotum is distinct in both sexes (Fig. 12A).

Body length. The literature (Wagner 1952, 1970, Wagner \& Weber 1964) gives the following sizes: male: $6.4-6.9 \mathrm{~mm}$, female: $6.0-7.0 \mathrm{~mm}$ (macropterous form) or 5.6-5.9 mm (pseudobrachypterous form). However some of the examined males were a little bigger - up to $7.1 \mathrm{~mm}$.

Biology. Specimens of this species lives on grasses, prefer dry places, but can be found also in wetter habitats. Adults are found from June to the end of July; it overwinters as an egg, and has one generation per year (Wachmann et al. 2004).

Distribution (according to Kerzhner \& Josifov 1999, Aukema et al. 2013; Fig. 2).

Europe: Austria, Belarus, Belgium, Bosnia and Herzegovina, Bulgaria, Croatia, Czech Republic, Denmark, France, Germany, Greece, Hungary, Italy, Kazakhstan (European part), Latvia, Liechtenstein, Lithuania, Luxembourg, Macedonia, Moldova, Netherlands, Poland, Romania, Russia (Central European Territory, South European Territory), Serbia, Slovakia, Spain, Switzerland, Ukraine. North Africa: Algeria, Tunisia (?).

Asia: Azerbaijan, Armenia, Kazakhstan (Asian part), Turkey (Asian part).

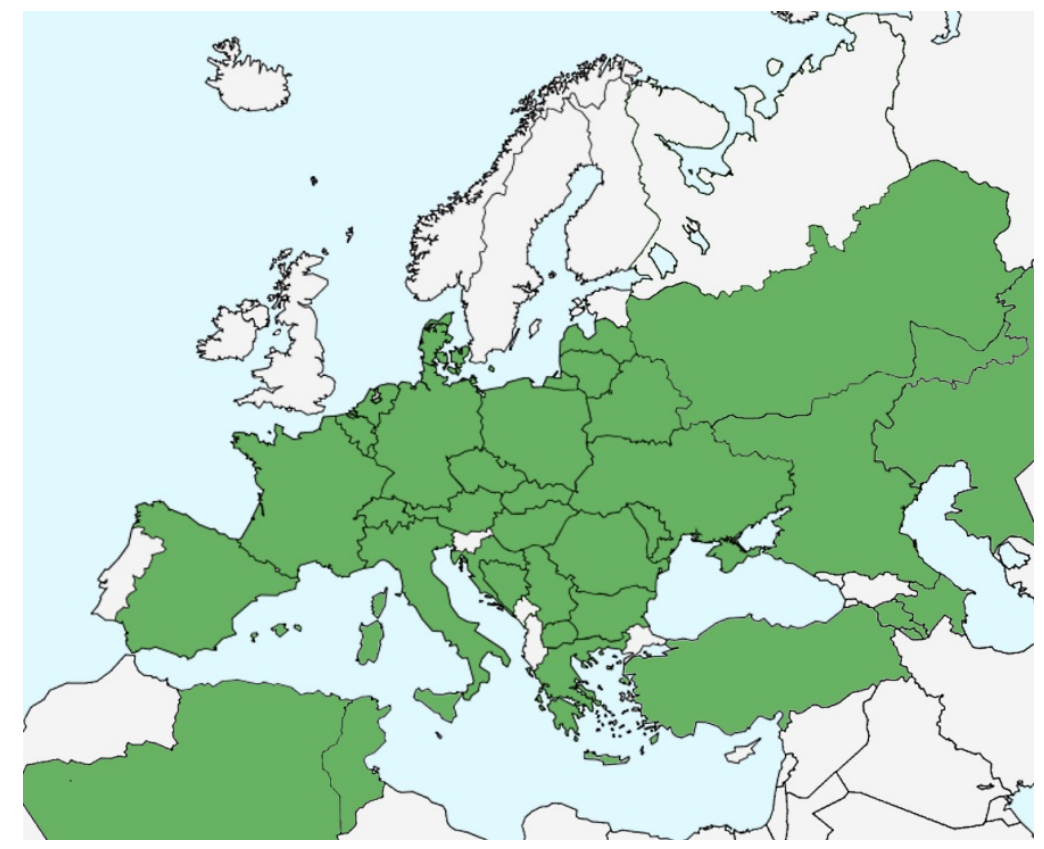

Fig. 2. Distribution of A. carinata in western Palaearctic (orig.) 
Occurrence in Poland (Fig. 3).

Literature data:

Eastern Beskidy: Przemyśl [FA21] - Smreczyński 1908, Gorczyca \& Wolski 2011.

Mazowiecka Lowland: Dziekanów Leśny [DC99] - Bilewicz-Pawińska 1965, Gorczyca \& Wolski 2011.

Sandomierska Lowland: Kłaj [DA53] - Stobiecki 1915, Smreczyński 1954, Gorczyca \& Wolski 2011.

Wielkopolsko-Kujawska Lowland: Bydgoszcz [BD99] - Szulczewski 1913, Gorczyca \& Wolski 2011; Czarnowska Górka [VU82] - Hebda \& Rutkowski 2015; Duninów [CD92] Strawiński 1965, Gorczyca \& Wolski 2011; Gorzewo [XU64] - Schumacher 1913, Gorczyca \& Wolski 2011; Puszcza Zielonka [XU42] - Skórka 1994, Gorczyca \& Wolski 2011; Turew [XT27] - Trojan 1989.

Baltic Coast: Gdańsk [CF42] - Stichel 1960, Gorczyca \& Wolski 2011; Słowiński National Park [XA46] - Korcz 2003, Gorczyca \& Wolski 2011; Świnoujście [VV57] - Wagner 1941, Gorczyca \& Wolski 2011.

Podlasie Lowland: Dolistowo [FE33] - Herczek 1982, Gorczyca \& Wolski 2011; Kramówka Mała [FE12] - Lis et al. 1995, Gorczyca \& Wolski 2011; Osowiec [FE02] - Lis et al. 1995, Gorczyca \& Wolski 2011.

Mazurian Lake District: Olsztyn [DE65] - Stichel 1960, Gorczyca \& Wolski 2011; Pisz [EE54] - Stichel 1960, Gorczyca \& Wolski 2011; Świętajno [EE88] - Strawiński 1957, Piasecka 1960, Gorczyca \& Wolski 2011.

Pomeranian Lake District: Gwda Wielka [XV15] - Burdajewicz \& Nowacka 1995, Gorczyca \& Wolski 2011; Kalisz Pomorski [WV60] - Herczek \& Nakonieczny 1987, Gorczyca \& Wolski 2011; Recz [WV30] - Karl 1935, Gorczyca \& Wolski 2011; Bielinek nad Odrą reserve [VU46] - Engel \& Hedicke 1934, Engel 1938, Gorczyca \& Wolski 2011.

Roztocze Upland: Tartaczna Góra reserve [FB30] - Strawiński 1966, Gorczyca \& Wolski 2011; Ulów [FA69] - Tenenbaum 1921, Gorczyca \& Wolski 2011; Wieprzec [FB51] Cmoluchowa \& Lechowski 1994, Lechowski \& Cmoluchowa 1996, Gorczyca \& Wolski 2011.

Eastern Sudetes Mts: Łąka Prudnicka [XR77] - Hebda \& Lis 2007, Gorczyca \& Wolski 2011; Trzebinia [XR87] - Hebda \& Lis 2007, Gorczyca \& Wolski 2011.

Lower Silesia: Gogolin [BA89] - Hebda 2006, Gorczyca \& Wolski 2011; Kamień Śląski [BB90] - Hebda 2006, Gorczyca \& Wolski 2011; Legnica [WS87] - Scholz 1931, Polentz 1944, Gorczyca \& Wolski 2011; Wrocław [XS46] - Polentz 1944, Gorczyca \& Wolski 2011.

Upper Silesia: Bieruń [CA64] - Gorczyca \& Wolski 2011; Bytom [CA58] - Lis 1989, Lis \& Lis 1998, Gorczyca \& Wolski 2011; Piekary Śląskie, Kocie Górki reserve [CA58] Bugaj-Nawrocka \& Gorczyca 2013; Tarnowskie Góry [CA49] - Lis 1989, Lis \& Lis 1998, Gorczyca \& Wolski 2011.

Krakowsko-Wieluńska Upland: Czerna [DA05] - Smreczyński 1906, Gorczyca \& Wolski 2011; Kraków [DA24] - Stobiecki 1915, Strawiński 1936, Smreczyński 1954, Gorczyca \& Wolski 2011; Kraków, Pychowice [DA14] - Smreczyński 1954, Gorczyca \& Wolski 2011. Ojcowski National Park [DA16] - Chłond \& Gorczyca 2009, Gorczyca \& Wolski 2011; Olsztyn [CB72] - Gorczyca 1994, Gorczyca \& Wolski 2011.

Lubelska Upland: Gołąb [EC60] - Cmoluchowa 1971, Gorczyca \& Wolski 2011; Janów Lubelski [EB91] - Piasecka 1960, Gorczyca \& Wolski 2011; Kazimierz Dolny [EB68] Cmoluchowa 1964, Gorczyca \& Wolski 2011, Krężnica Jara [FB06] - Cmoluchowa 1971, Gorczyca \& Wolski 2011; Lublin, botanical garden [FB08] - Cmoluchowa 1960, Gorczyca \& Wolski 2011; Opoka [EB63] - Cmoluchowa 1971, Gorczyca \& Wolski 2011; Sawin [FB68] Cmoluchowa \& Lechowski 1992; Gorczyca \& Wolski 2011; Wrotków [FB07] - Buczek 1956, Gorczyca \& Wolski 2011; Wólka Profecka [EB69] - Strawiński 1963, Zaklików [EB72] - 
Cmoluchowa 1971, Gorczyca \& Wolski 2011; Zemborzyce [FB07] - Buczek 1956, Gorczyca \& Wolski 2011.

Małopolska Upland: Pińczów [DA69] - Herczek 1987, Gorczyca \& Wolski 2011, Miedzianka reserve [DB53] - Walczyk 2009.

Poland (generally): Stichel 1933, 1956, Cmoluchowa \& Mielewczyk 1990, Kerzhner \& Josifov 1999, Gorczyca 2004, Gorczyca \& Wolski 2011.

Pomerania: Stichel 1933, Gorczyca \& Wolski 2011.

Prussia: Brischke 1871, Stichel 1933, Gorczyca \& Wolski 2011.

Silesia: Scholz 1931, Stichel 1933, Gorczyca \& Wolski 2011.

New records:

Upper Silesia: Ruda Śląska [CA46] 3 Jun 2000, 1 ex., 6 Jun 2000, 4 exx., leg. \& det. A. Kołodziej; Miasteczko Śląskie [CA59] 28 Jun 1986, 2 exx., 8 Jul 1986, 2 exx., leg \& det. J. Lis; Mysłowice [CA66] 2 Jul 1985, 7 exx., leg. \& det. B. Bojda; Imielin [CA75] 11 Jun 2017, 6 exx., leg. \& det. A. Taszakowski; Mitręga [CA88] 5 Jun 2001, 1 ex., leg. \& det. I. Romik; Lubliniec (Kokotek) [CB30] 12 Jul 1994, 2 exx., leg. \& det. M. Miszok.

Małopolska Upland: Skorocice [DA78] 14 Jun 2005, 1 ex., leg. \& det. P. Bętka.

Pomerania Lake District: Borne Sulinowo [XV03] 4 Jul 1997, 1 ex., leg. \& det. E. Pilarska.

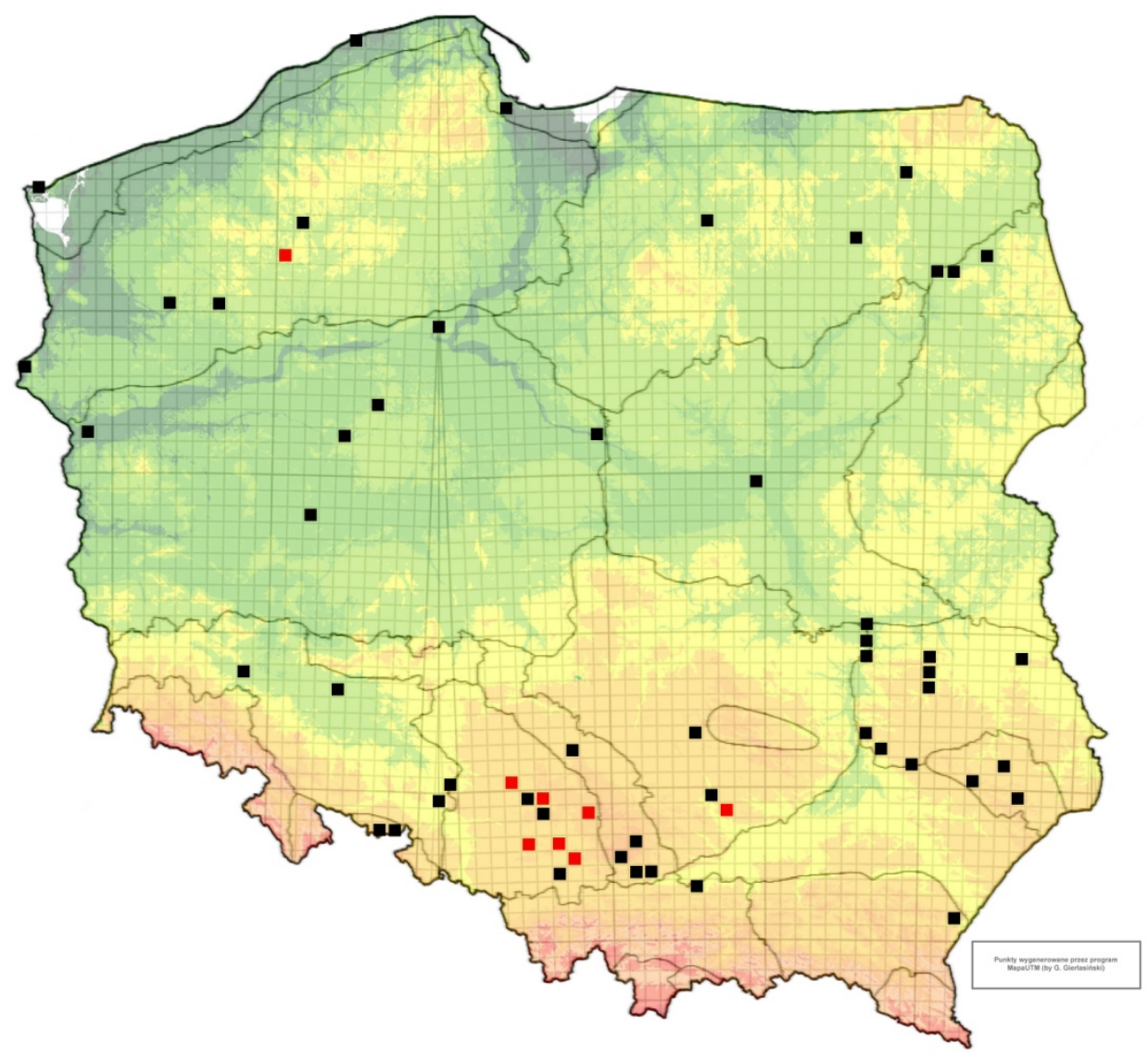

Fig. 3. Distribution of A. carinata in Poland; black colour - literature data, red - new records. 


\section{Acetropis gimmerthalii (Flor, 1860)}

Taxonomy. There are two subspecies: A. gimmerthalii gimmerthalii (Flor, 1860) and A. gimmerthalii parva (Wagner 1968). In Poland occurs the nominative subspecies.

Morphology. Colouration is similar to the previous species, but often the male is paler, same coloured, or slightly more contrasted in colour than the female (Fig. 1B, E). The second segment of the antennae is bright, except for the apical part (Fig. 10A). Legs and antennae are covered with distinct black hair (Fig. 10A). Carina of pronotum is visible only in the middle part of pronotum (Fig. 12B). Female are mostly pseudobrachypterous.

Body length (A. gimmerthalii gimmerthalii). The literature (Wagner 1952, 1970, Wagner \& Weber 1964) gives the following sizes: male: $4.8-5.6 \mathrm{~mm}$, female: $6.0-7.0 \mathrm{~mm}$ (macropterous form), 5.5-6.4 mm (pseudobrachypterous form). Measurements made on the basis of specimens from the authors' collection show that the males can reach up to $6.3 \mathrm{~mm}$.

Biology. Like in the previous species, found in habitats of varying humidity.

Distribution (according to Kerzhner \& Josifov 1999, Silfverberg 2012, Aukema et al. 2013, Lukashuk 2013; Fig. 4).

A. gimmerthalii gimmerthalii: Europe: Belarus, Belgium, Czech Republic, Denmark, Estonia, Finland, France, Great Britain, Germany, Greece, Italy, Latvia, Lithuania, Luxembourg, Macedonia, Montenegro, Netherlands, Poland, Portugal, Russia (Central European Territory, North European Territory), Spain, Sweden, Ukraine. North Africa: Algeria, Canary Islands, Morocco.

A. gimmerthalii parva: Europe: France, Portugal.

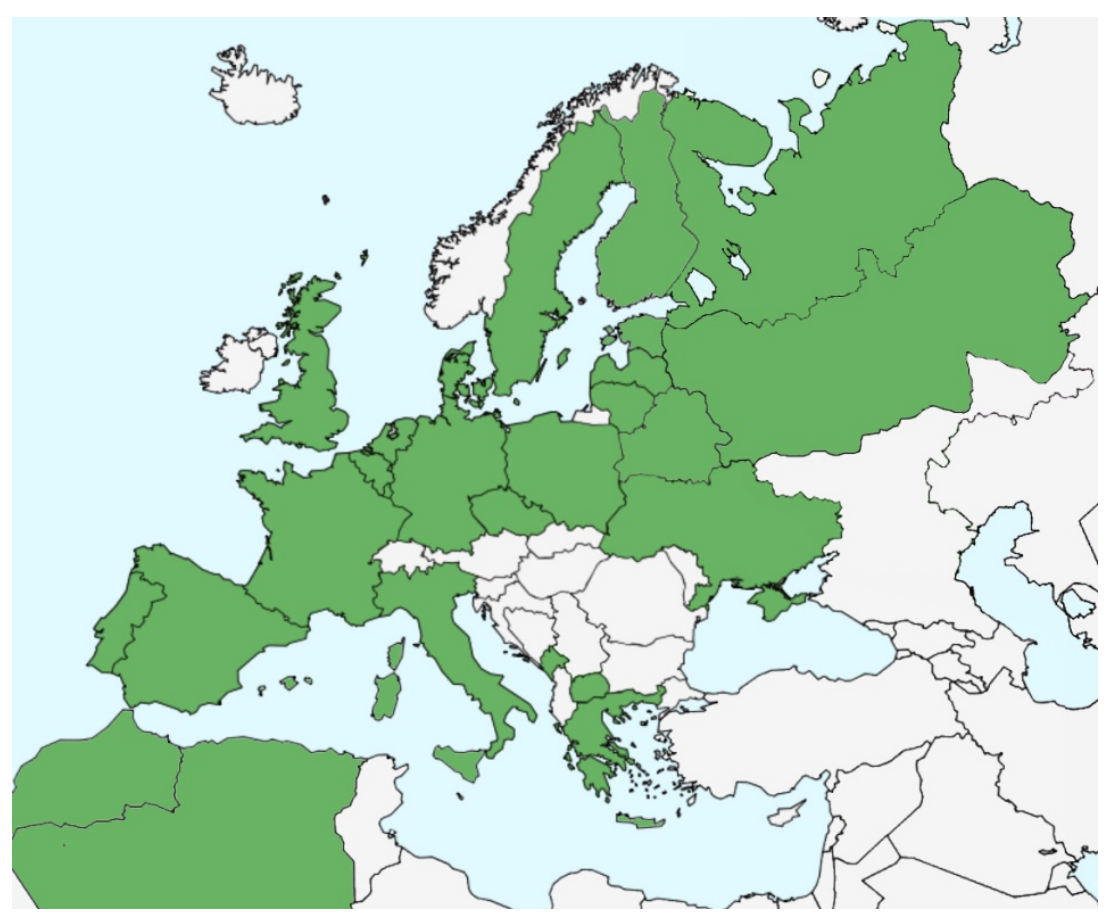

Fig. 4. Distribution of A. gimmerthalii in western Palaearctic (orig.) 
Occurrence in Poland (Fig. 5).

Literature data:

Mazowiecka Lowland: Kampinos [DC69] - Cmoluchowa 1977, Gorczyca \& Wolski 2011.

Podlasie Lowland: neighbourhood of Mielnik (Sutno) [FC49] - Gorczyca \& Herczek 1991, Gorczyca \& Wolski 2011 (individuals previously mistakenly referred to as A. carinata).

Pomeranian Lake District: Pomierzyn [WV51] - Cmoluchowa 1977, Gorczyca \& Wolski 2011.

Białowieża Forest: Białowieża [FD94] - Hebda 2011.

Krakowsko-Wieluńska Lowland: Olsztyn [CB72] - Gorczyca 1994 (individuals previously mistakenly referred to as A. carinata); Przedmość [CB16, CB26] - Noga \& Lis 2015.

Western Beskidy: Brenna, Stary Groń Massif [CA50] - Matuszczyk \& Taszakowski 2017.

Poland (generally): Stichel 1956; Cmoluchowa \& Mielewczyk 1990, Kerzhner \& Josifov 1999, Gorczyca 2004, Gorczyca \& Wolski 2011.

New records [asterisk $\left(^{*}\right)$ marks zoogeographical regions in which A. gimmerthalii were recorded for the first time]:

* Wielkopolsko-Kujawska Lowland: Krośnice [XT60] 29 Jun 2017, leg. Ł. Depa, det. A. Taszakowski.

* Baltic Coast: Bałamątek [XA35] 30 Jun 2014, 2 exx., leg. T. Rutkowski, det. G. Hebda.

Pomerania Lake District: Drzewicz [XV66] Bory Tucholskie National Park, 5 Jul 2014, 15 exx., leg. T. Rutkowski, det. G. Hebda.

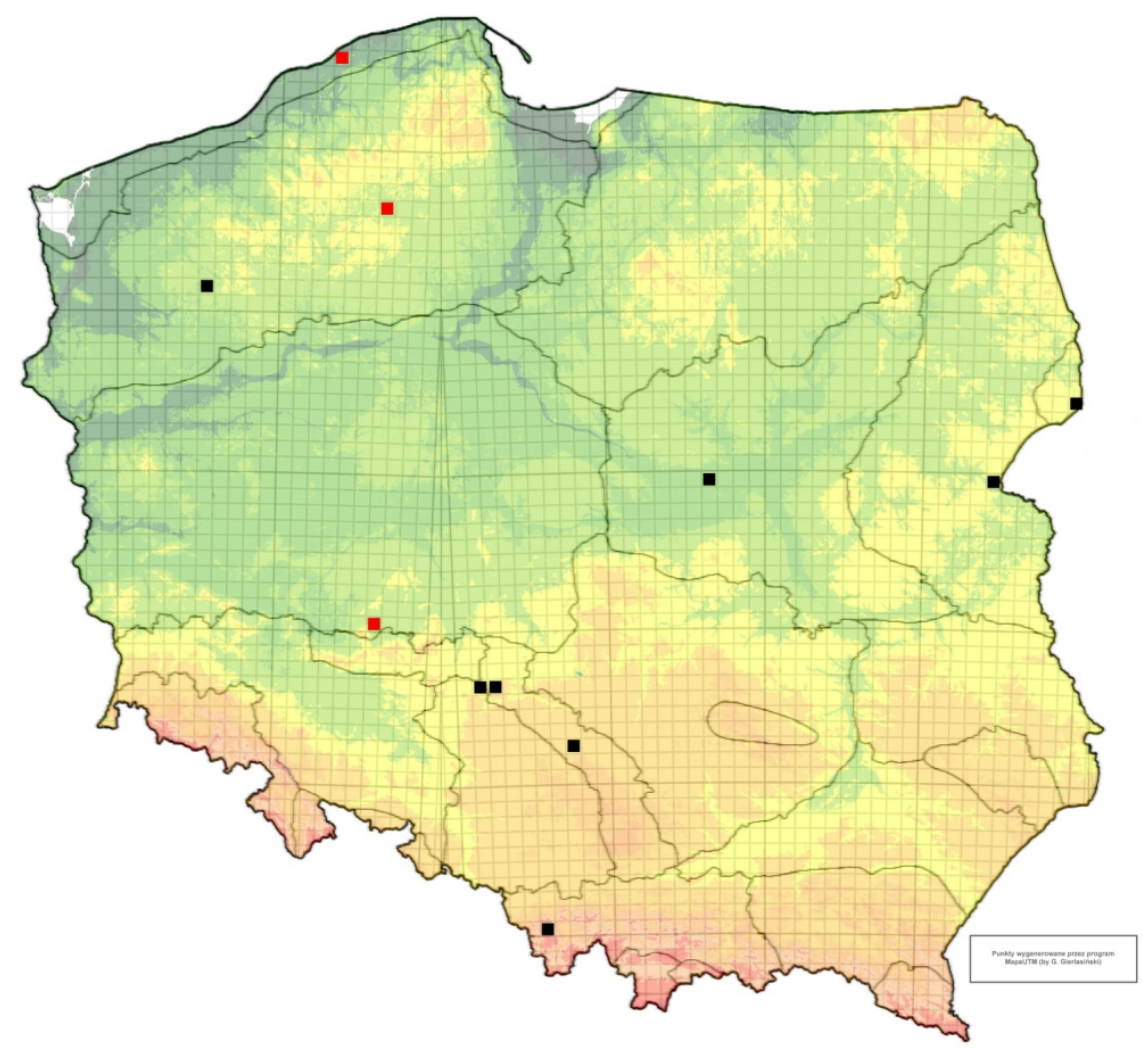

Fig. 5. Distribution of A. gimmerthalii in Poland; black colour - literature data, red - new records 


\section{Acetropis longirostris Puton, 1875}

Morphology. Sexual dimorphism is poorly marked. The colouration of females is similar to that of the previous species, the males are less contrasting in colour. Head is yellow with dark stripe running in the middle. Pronotum has three dark, longitudinal stripes, almost without carina. Scutellum, in males, is often yellow-orange (in females of the same colour as the rest of the body). Femora and tibiae are in body colour, tarsi are darker. Clypeus is short and fairly bluntly terminated, labium is not covered by apex of the clypeus, while in the two previous species the clypeus is elongated, pointed (well visible from the side) and covers the labium. Rostrum reaches at least the 2nd abdominal sternite, but sometimes can also reach the 4th abdominal sternite. Males macropterous, females pseudobrachypterous to various extent. Body length: Štys (1973) gives as follow: male (macropterous form): $6.3-7.1 \mathrm{~mm}$, females (pseudobrachypterous form): 6.4-8.3 $\mathrm{mm}$ (up to $9 \mathrm{~mm}$ ). However, measurements made on the basis of specimens from the authors' collection show that the size range is bigger: males can reach up to $8.0 \mathrm{~mm}$, females with very shortened wings can be only $6.3 \mathrm{~mm}$ in length (Fig. 6) while the largest specimens can reach up to $9.1 \mathrm{~mm}$.

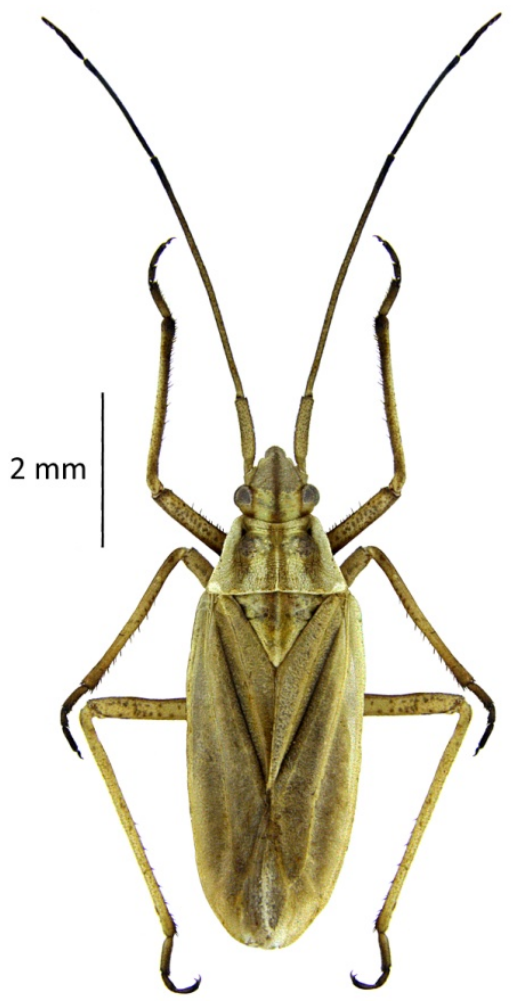

Fig. 6. A. longirostris, pseudobrachypterous form. Photo by A. Taszakowski.

Biology. Feeds on Alopecurus pratensis (L.) (Štys 1973, 1974; Wachmann et al. 2004). Adults are found from late May to early July (Fig. 7), but single specimens can be found much later (Gierlasiński 2015a). 


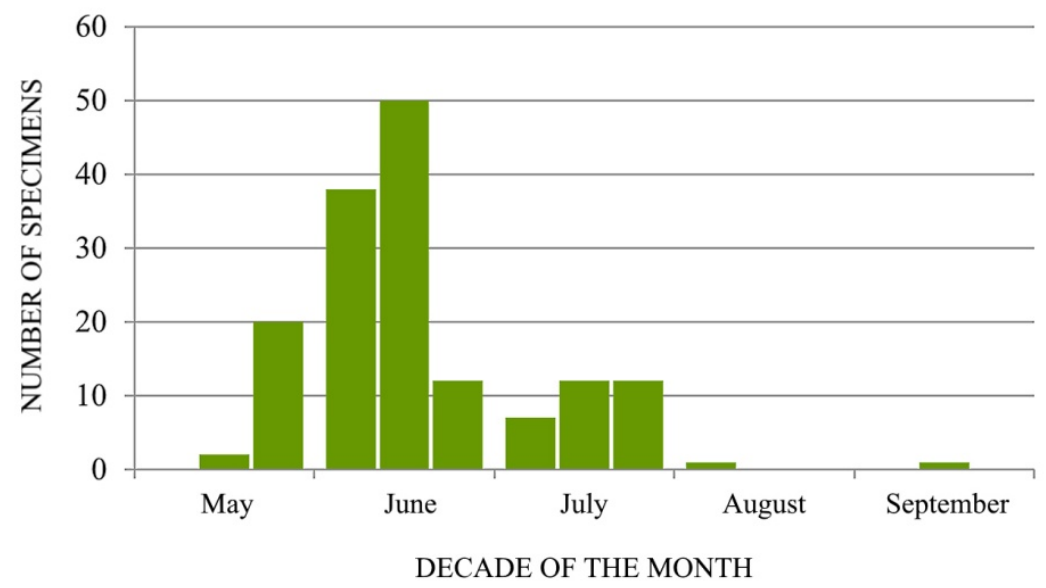

Fig. 7. Changes in the abundance of A. longirostris.

Distribution (according to Kerzhner \& Josifov 1999, Aukema et al. 2013, Nikolaeva \& Ruchin 2016; Fig. 8).

Europe: Austria, Czech Republic, Hungary, Kazakhstan (European part), Montenegro, Russia (Central European Territory, South European Territory), Serbia, Slovakia, Ukraine.

Asia: Azerbaijan, Kazakhstan (Asian part).

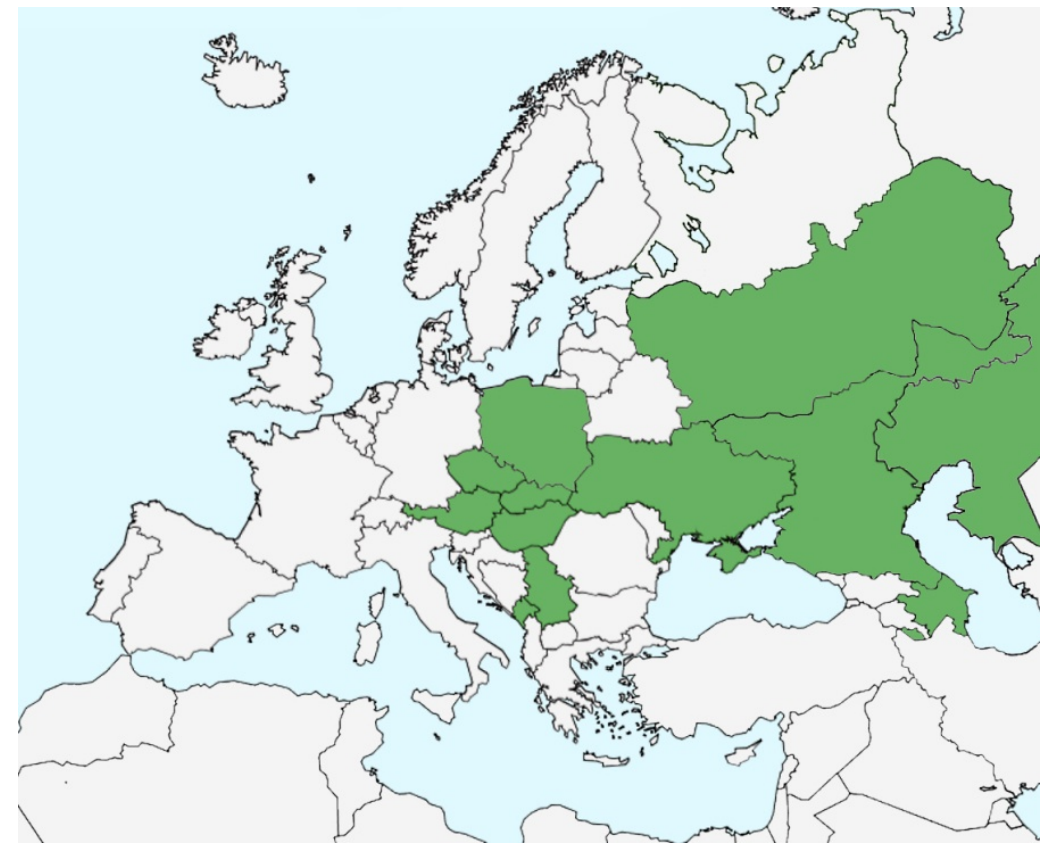

Fig. 8. Distribution of A. longirostris in western Palaearctic (orig). 
Occurrence in Poland (Fig. 9).

Literature data:

Western Beskidy: Meszna [CA51] - Lis \& Dubiel 2013; Brenna, Stary Groń Massif [CA50] - Matuszczyk \& Taszakowski 2017.

Eastern Beskidy: Lipniki [EA20], Dobrynia [EV39], Libusza [EA10], Nowy Żmigród [EV39] - Taszakowski \& Gorczyca 2018.

Bieszczady Mts: Żebrak Pass [EV85] - Gierlasiński 2015a.

Upper Silesia: Bogacica [BB95] - Hanus \& Lis 2014; Jełowa [BB93] - Cieśliczka \& Lis 2015; Witkowice ad Kęty [CA73] - Gierlasiński 2015b.

Krakowsko-Wieluńska Upland: Przedmość [CB16, CB26] - Noga \& Lis 2015.

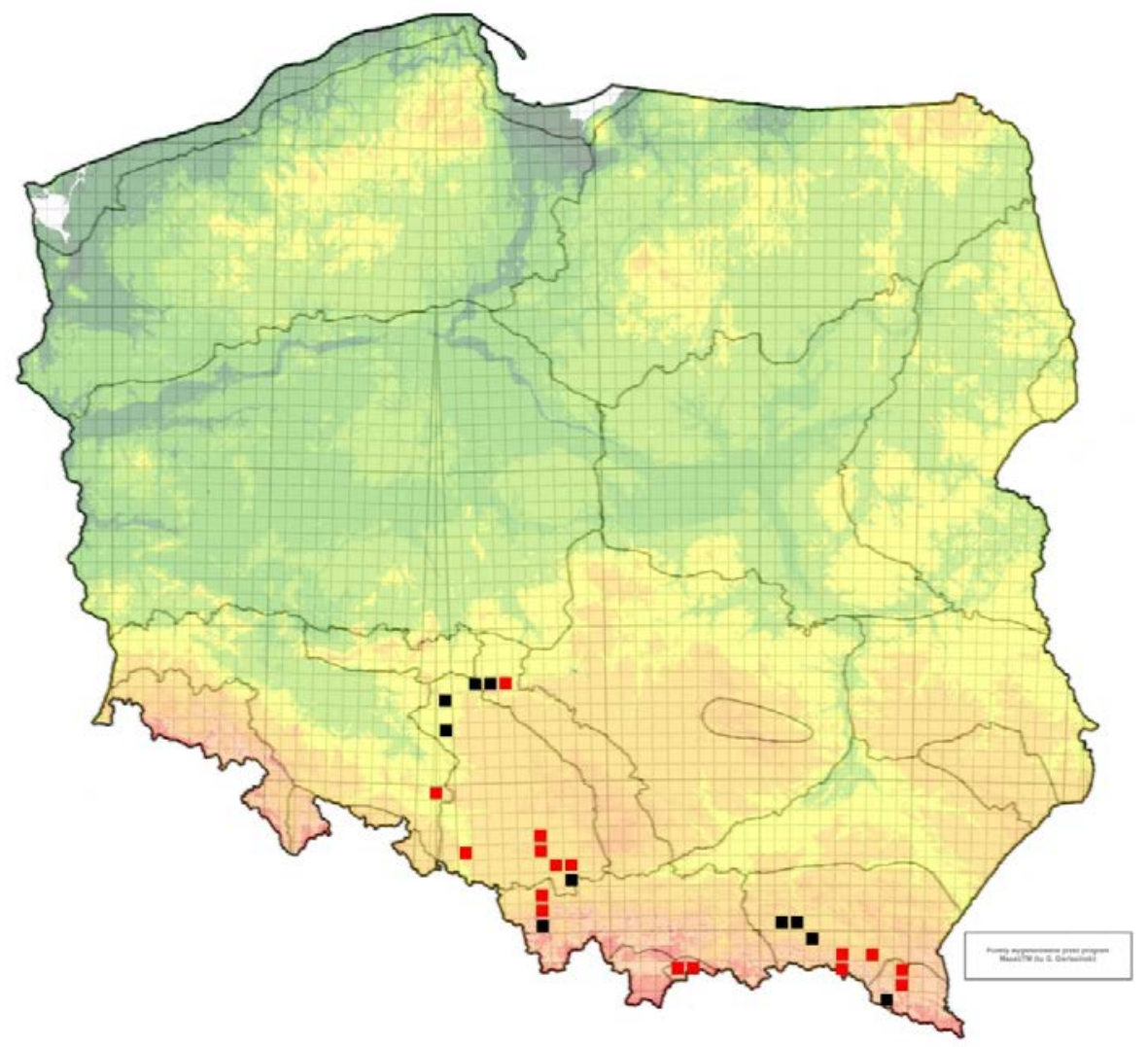

Fig. 9. Distribution of A. longirostris in Poland; black colour - literature data, red - new records.

New records [asterisk $(*)$ marks zoogeographical regions in which A. gimmerthalii were recorded for the first time]:

Western Beskidy: Bielsko-Biała, Komorowice [CA52] 7 Jun 2016, 2 exx., 26 Jun 2016, 1 ex., leg. \& det. G. Gierlasiński; Bielsko-Biała, Wapienica [CA51] 7 Jun 2016, 6 exx., leg. \& det. G. Gierlasiński; Bielsko-Biała, Stare Bielsko [CA52] 9 Jun 2016, 2 exx., leg. \& det. G. Gierlasiński; Bielsko-Biała, Dolina Gościnna [CA51] 28 Jun 2016, 1 ex., leg. \& det. G. Gierlasiński; Rajcza [CV68] 8 Jun 2016, 7 exx., leg. \& det. G. Gierlasiński; Kicznia [DV59], 11 Jun 2017, 1 ex., leg. \& det. G. Gierlasiński. 
Eastern Beskidy: Lipowiec [EV57] 15 Jun 2017, 5 exx., leg. \& det. G. Gierlasiński; Królik Polski [EV58] 15 Jun 2017, 2 exx., leg. \& det. G. Gierlasiński; Odrzechowa [EV78] 15 Jun 2017, 7 exx., leg. \& det. G. Gierlasiński.

Bieszczady Mts: Mchawa [EV96] 16 Jun 2017, 2 exx., leg. \& det. G. Gierlasiński; Lesko [EV97] 17 Jun 2017, 4 exx., leg. \& det. G. Gierlasiński.

* Lower Silesia: Żywocice [YR19] 25 May 2009, wet meadow over Odra river, 2 exx., leg. M.A. Mazur, det. G. Hebda.

Upper Silesia: Tychy [CA55] 12 Jun 2008, 6 exx., 17 Jun 2008, 6 exx., 23 Jun 2008, 1 ex., 29 Jun 2008, 2 exx., 6 Jul 2008, 1 ex., 11 Jul 2008, 1 ex., 19 Jul 2008, 7 exx., 23 Jul 2008, 5 exx., leg. J. Kania, det. A. Taszakowski; Bieruń Nowy [CA64] 26 May 2005, 6 exx., leg. A. Kielar, det. A. Taszakowski; Łężczok reserve [CA05] 19 Jun 2006, 3 exx., leg. T. Masarczyk, det. A. Taszakowski; Brzezinka [CA74] 23 May 2009, 9 exx., 8 Jun 2009, 4 exx., leg. K. Rydzoń, det. A. Taszakowski; Katowice, Podlesie [CA56] 04 Jun 2009, 1 ex., 15 Jun 2009, 4 exx., 24 Jun 2009., 5 exx., 6 Jul 2009., 5 exx., 16 Jul 2009., 4 exx., 24 Jul 2009., 7 exx., leg. A. Kempny, det. A. Taszakowski.

* Pieniny Mts: Czorsztyn [DV57] 27 Jun 2001, 1 ex., 1 Jul 2001, 1 ex.; Falsztyn [DV47] 8 Aug 2001, 1 ex., leg. A. Fryc, det. A. Taszakowski

Krakowsko-Wieluńska Upland: Kępowizna [CB36] 22 Jun 2001, 1 ex., leg. R. Bolek, det. A. Taszakowski.

\section{KEY TO IDENTIFICATION OF THE ACETROPIS SPECIES OCCURRING IN POLAND}

1. Second segment of antennae (Fig. 10A) and femurs with numerous, long setae

A. gimmerthalii Puton, 1875

- Second segment of antennae (Fig. 10B, C) and femurs without long setae

2. Rostrum reaches at most the anterior margin of the hind coxa (Fig. 11A)

A. carinata (Herrich-Schaeffer, 1841)

- Rostrum reaches at least the second abdominal sternite (Fig. 11B)

A. longirostris (Flor, 1860)

Notes: Pay attention to the proper arrangement (parallel to the body) of the insect's head. Due to the possible difficulties of perception and interpretation used in key features, other features that differentiate the above species have been summarized in the Table below and in the Figs 10-12.

\section{DISCUSSION}

Acetropis carinata is the most common species of the genus Acetropis in Poland, which is known from all over Poland. Acetropis gimmerthalii is the least often collected, however, it seems, that it can be present also on larger territory of the country. Acetropis longirostris occurs only in southern Poland.

The first data on the occurrence of A. longirostris in Poland was presented by Lis B. \& Dubiel (2013). During the analysis of material deposited in the collection of the Department of Zoology, Faculty of Biology and Environmental Protection, University of Silesia in Katowice, it turned out that $A$. longirostris specimens have already been collected many times (for the first time in 2001), however, it was mistakenly identified as A. carinata. The reason for this confusion was probably prosaic - the key used for the identification of the plant bugs (Wagner \& Weber 1964) does not include A. longirostris, because this species is not present in France (this key concerns this area). Nevertheless, taking into account the long tradition of heteropterological research in Poland, it seems that A. longirostris appeared in Poland only in the 21st century. 
Table. Summary of the features distinguishing three species of Acetropis occurring in Poland.

\begin{tabular}{|c|c|c|c|}
\hline Feature & A. carinata & A. gimmerthalii & A. longirostris \\
\hline rostrum,$+ \sigma^{\lambda}$ & $\begin{array}{l}\text { reaches at most the } \\
\text { anterior margin of the } \\
\text { hind coxa }\end{array}$ & $\begin{array}{l}\text { reaches at most the anterior } \\
\text { margin of the hind coxa }\end{array}$ & $\begin{array}{l}\text { reaches at least the second } \\
\text { abdominal sternite }\end{array}$ \\
\hline $\begin{array}{l}\text { second segment of } \\
\text { antennae and femurs }+ \text {, } \\
\hat{\delta}\end{array}$ & $\begin{array}{l}\text { without numerous, long } \\
\text { setae }\end{array}$ & with numerous, long setae & $\begin{array}{l}\text { without numerous, long } \\
\text { setae }\end{array}$ \\
\hline $\begin{array}{l}\text { anterior margin of } \\
\text { pronotum } \$, \lambda\end{array}$ & with distinct carina & $\begin{array}{l}\text { carina visible only in the } \\
\text { middle part of pronotum }\end{array}$ & without carina \\
\hline collum $+\stackrel{0}{\sigma}$ & $\begin{array}{l}\text { posteriorly distinctly } \\
\text { delimited by a deep } \\
\text { transverse furrow }\end{array}$ & posteriorly not limited & $\begin{array}{l}\text { posteriorly distinctly } \\
\text { delimited by a deep } \\
\text { transverse furrow }\end{array}$ \\
\hline frons,$+ \hat{\sigma}$ & $\begin{array}{l}\text { strongly produced } \\
\text { anteriorly, completely } \\
\text { covering the anteclypeus } \\
\text { in dorsal view }\end{array}$ & $\begin{array}{l}\text { moderately produced } \\
\text { anteriorly, anteclypeus } \\
\text { always exposed in dorsal } \\
\text { view }\end{array}$ & $\begin{array}{l}\text { moderately produced } \\
\text { anteriorly, anteclypeus } \\
\text { always exposed in dorsal } \\
\text { view }\end{array}$ \\
\hline $\begin{array}{l}\text { pronotal median carina } \\
0, \hat{0}\end{array}$ & $\begin{array}{l}\text { thick, percurrent, keel- } \\
\text { like, strongly raised }\end{array}$ & distinct only in the middle & $\begin{array}{l}\text { linear, almost not raised, } \\
\text { percurrent to partly or } \\
\text { completely reduced }\end{array}$ \\
\hline body length $q$ & $5.6-7.0 \mathrm{~mm}$ & $5.5-7.0 \mathrm{~mm}$ & $6.3-9.1 \mathrm{~mm}$ \\
\hline colouration $\hat{\partial}$ & $\begin{array}{l}\text { usually gray or almost } \\
\text { black }\end{array}$ & $\begin{array}{l}\text { usually pale, little } \\
\text { contrasting }\end{array}$ & $\begin{array}{l}\text { usually pale, slightly } \\
\text { contrasting }\end{array}$ \\
\hline vesica $\lesssim$ & with two spiculae & with two spiculae & with three spiculae \\
\hline body length $\hat{\sigma}$ & $6.4-7.1 \mathrm{~mm}$ & $4.8-6.3 \mathrm{~mm}$ & $6.3-8.0 \mathrm{~mm}$ \\
\hline
\end{tabular}

A

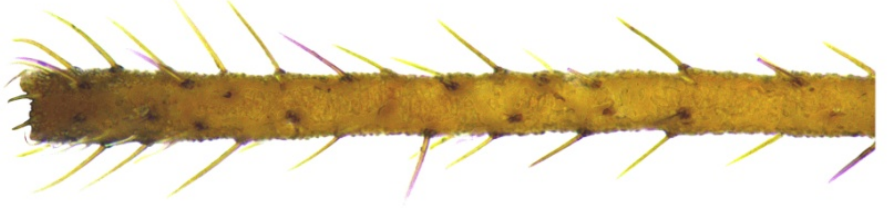

B

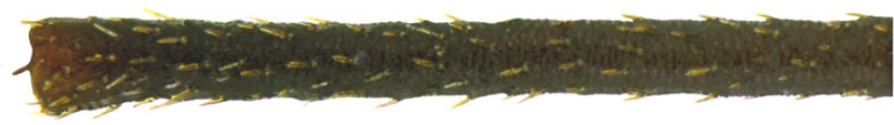

$\mathrm{C}$

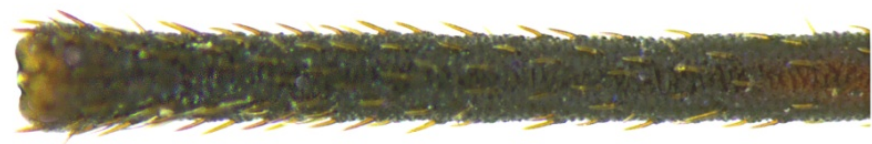

$0,2 \mathrm{~mm}$

Fig. 10. Distal part of the second antennal segment: A - A. gimmerthalii, $q, \mathrm{~B}-\mathrm{A}$. carinata, $q, \mathrm{C}-\mathrm{A}$. longirostris, $q$ Photo by A. Taszakowski.

Acetropis longirostris clearly expands its area of occurrence and it is often defined as an expansive species (Hradil et al. 2008, Rabitsch 2008, Roháčová 2011, Friess \& Brandner 2014). Its dispersion center probably lies in the steppes of the Eastern Europe. The species was recorded in Slovakia (single female in 1960 and many specimens in 1973) (Štys 1974), in Austria in 1983 (Rabitsch 2008), and in the Czech Republic a year later (South Moravia) 
(Stehlík 1988). Faunistic studies conducted in Austria have shown a rapid expansion of the range of this species to the west (Friess \& Brandner 2014). According to Štys (1974), the drastic agricultural modification of the landscape was probably the factor responsible for population explosion of A. longirostris in Slovakia. However Rabitsch (2008) claims that the climate warming is a reason of expansion of this species in Austria. Recent climate changes (Kożuchowski 2011) are often postulated responsible for changes in the range of occurrence of many insects (e.g. Menéndez 2007, Rabitsch 2008, Taszakowski \& Gorczyca 2018). Since the expansion in Central Europe started already in 1960s and proceeded not from south to north but from east to west, from regions with continental to oceanic climate (and then to the north), further research are still needed to determine the reasons.
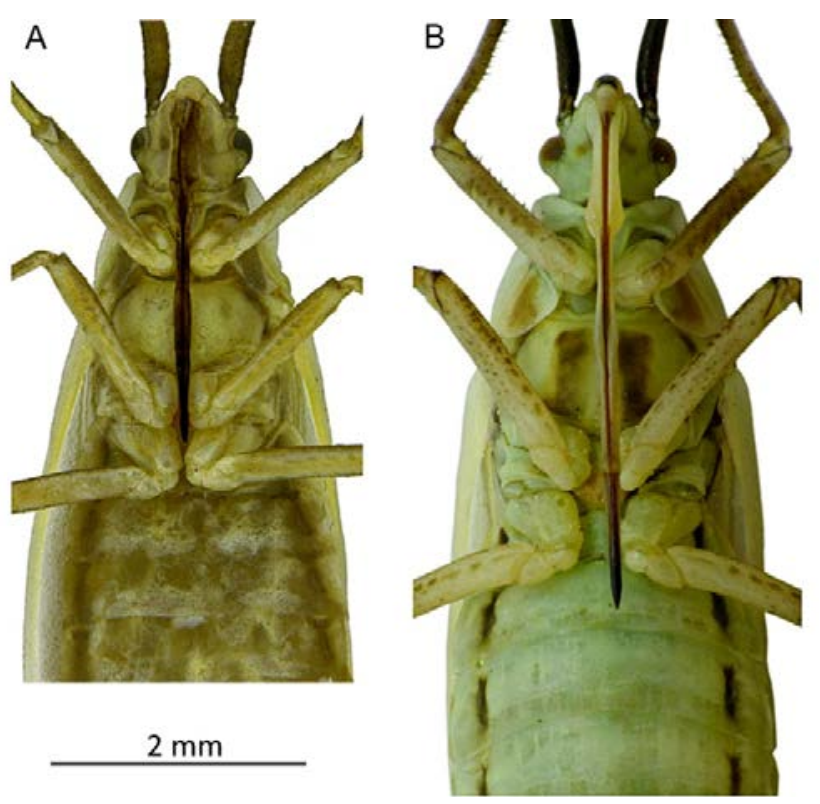

Fig. 11. Labium: A - A. carinata, + (photo by A. Taszakowski), B - A. longirostris, $\rightarrow$ [according to Gierlasiński (2015b), modified].

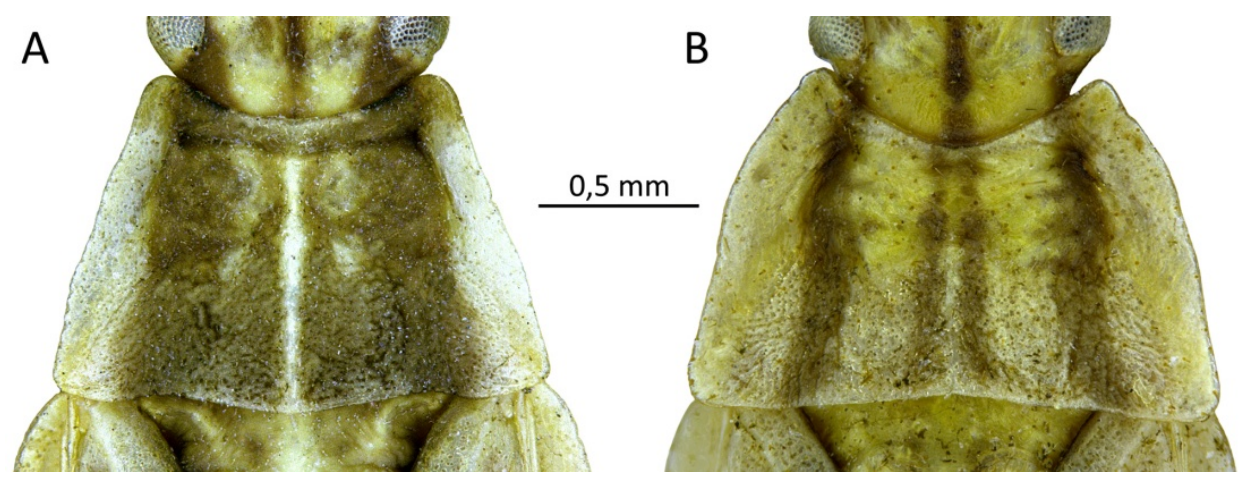

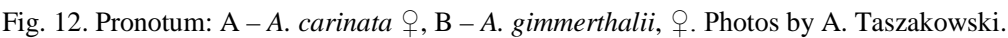


Analyzing the potential immigration routes of the Heteroptera species with southern type of distribution (Taszakowski \& Gorczyca 2018), it seems that the Moravian, Spisz and Ondavian migratory routes are probable ways of immigration of $A$. longirostris into the territory of Poland. It is also possible that this species immigrates by the eastern way (Podolian). However, to confirm this hypothesis, it is necessary to carry out more faunistic studies, especially in the vicinity of Przemyśl.

Acetropis longirostris is likely to be found in Moldova and Romania and west: in southern Germany, western parts of France and Switzerland, as well as northern Italy, Slovenia and Croatia. Also the discovery of A. gimmerthalii in other Central European countries is possible.

For the better knowledge of the occurrence of representatives of Acetropis further faunistic studies are necessary. They should be conducted in June, because later in the year these bugs are found much less frequently. Nevertheless, collecting the adult individuals of A. longirostris in late July, August and even September (Gierlasiński 2015a) may indicate the second generation in a year. Changes in the phenology of species are a frequent result of climate changes and can favour the expansion of species (Musolin 2007, Lis \& Ziaja 2009, Depa et al. 2015, Taszakowski \& Gorczyca 2018). Unfortunately, authors of faunistic papers often do not provide the exact dates of the collecting, which causes that possibility of analyzing the phenology of species is greatly reduced.

Due to the fact that true bug species are taxa, whose changes in range of occurrence, abundance, phenology, number of generation, physiology, behaviour and structure of communities allow the assessment of the climate fluctuation and other environmental changes (Taszakowski \& Gorczyca 2018), it is advisable to conduct further faunistic studies on these insects.

\section{ACKNOWLEDGEMENTS}

We would like to express our gratitude to Grzegorz Hebda (Department of Biosystematics, Opole University, Poland) for providing the data on new sites and presenting us with the specimens of Acetropis gimmerthalii for taking pictures. We are very grateful to the Reviewers, who greatly improved the current version of the manuscript.

\section{REFERENCES}

AukemA B. 2013. Fauna Europaea: Acetropis Fieber, 1858. Fauna Europaea. Available at http.//faunaeur.org (version: Aug 2017).

Aukema B., Rieger C. \& RABitsch W. 2013. Catalogue of the Heteroptera of the Palaearctic Region 6: Supplement. The Netherlands Entomological Society, Wageningen: 629 pp.

BILEWICZ-PAwIŃSKA T. 1965. Ecological analysis of Heteroptera communities in cultivated fields. Ekologia Polska 13 (29): 593-639.

BRISCHKE C. G. A. 1871. Verzeichniss der Wanzen und Zirpen der Provinz Preussen. Schriften der Naturforschenden Gesellschaft in Danzig: neue Folge 2: 26-40.

BUCZEK D. 1956. Obserwacje nad biologią i morfologią stadiów larwalnych pluskwiaków (Hem.-Heter.) z podrodziny Mirinae (Miridae) stwierdzonych na łąkach w okolicach Lublina. Annales Universitatis Mariae CurieSkłodowska, C, Biologia 11 (10): 269-314.

Bugaj-NAWrocka A. \& GorczYCA J. 2013. The terrestrial true bugs (Hemiptera: Heteroptera) of Kocie Górki, Piekary Śląskie (Upper Silesia). Entomological News 32 (2): 118-126. [In Polish with English Abstract and Summary].

Burakowski B., MroczKowski M. \& StefańskA J. 1973. Chrząszcze Coleoptera. Biegaczowate - Carabidae, 1. Katalog fauny Polski 23 (2). PWN, Warszawa 232 pp.

BuRDAJEWICZ S. \& NowACKA W. 1995. Entomofauna of the glades in the forest district of Gwda Wielka. Part II. Bugs (Heteroptera). Entomological News 14 (1): 21-25. [In Polish with English Abstract].

ChŁond D. \& Gorczyca J. 2009. Terrestrial True Bugs (Hemiptera, Heteroptera) of the Ojców National Park Origin of Fauna. Annals of the Upper Silesian Museum, Entomology 17: 5-109. 
CIEŚLICZKA A. \& Lis B. 2015. True-bugs (Hemiptera: Heteroptera) of selected meadow communities of Jełowa (Opole voivodeship). Heteroptera Poloniae - Acta Faunistica 9: 11-15. [In Polish with English Abstract and Summary].

Cmoluchowa A. 1960. Obserwacje nad Hemiptera - Heteroptera Ogrodu Botanicznego UMCS. Annales Universitatis Mariae Curie-Skłodowska, C, Biologia 15 (7): 161-175.

CMoluchowA A. 1964. Pluskwiaki różnoskrzydłe (Hemiptera - Heteroptera) roślinnych zespołów kserotermicznych okolic Kazimierza nad Wisłą. Annales Universitatis Mariae Curie-Skłodowska, C, Biologia 19 (4): $49-94$.

Cmoluchowa A. 1971. Heteroptera of the Dunes in the Lublin Region. Annales Universitatis Mariae CurieSkłodowska, C, Biologia 26 (12): 129-153.

Cmoluchowa A. 1977. Studies on land bugs (Heteroptera) of Poland. II. Polish Journal of Entomology 47: 23-26. [In Polish with English Abstract].

Cmoluchowa A. \& LechowsKi L. 1992. Changes in Heteroptera Groups in Dry-ground Forest Communities near Sawin, Chełm Province. Annales Universitatis Mariae Curie-Skłodowska, C, Biologia 44 (3): 79-90.

Cmoluchowa A. \& LechowsKi L. 1994. Land Heteroptera of Roztocze. Fragmenta Faunistica 37 (7): 181-199. [In Polish with English Abstract and Summary].

CMoluchowA A. \& MielewCZYK S. 1990. Heteroptera - Pluskwiaki różnoskrzydłe Pp. 71-90. In: RAZOWSKi J. (ed.), Checklist of Animals of Poland. Vol. 1. Part XXXII1-20 Insecta: Protura-Planipennia. Institute of Systematics and Evolution of Animals, PAS, Kraków.

DEPA Ł., TASZAKOWSKI A.\& KANTURSKI M. 2015. Impact of warm weather events on prolongation of the life cycle of Stomaphis Walker (Hemiptera, Aphididae, Lachninae). Turkish Journal Of Zoology 39 (669): 1-3; DOI: 10.3906/zoo-1404-6

ENGEL H. 1938. Beiträge zur Flora und Fauna der Binnendüne bei Bellinchen (Oder). Märkische Tierwelt 3 (4): $229-294$.

Engel H. \& Hedicke H. 1934. Die Fauna der Binnendüne bei Bellinchen (Oder). IV. Die Tierwelt. Heteroptera. Märkische Tierwelt 17: 240-246.

FRIESS T. \& BRANDNER J. 2014. Interessante Wanzenfunde aus Österreich und Bayern (Insecta: Heteroptera). Joannea Zoologie 13: 13-127.

GIERLASIŃSKI G. 2015a. Acetropis longirostris Puton, 1875 (Hemiptera: Heteroptera: Miridae) - first record in Bieszczady Mountains. Heteroptera Poloniae - Acta Faunistica 9: 1-2. [In Polish with English Abstract and Summary].

GIERLASIŃSKI G. 2015b. Acetropis longirostris Puton, 1875 (Hemiptera: Heteroptera: Miridae) - a new locality in Upper Silesia. Heteroptera Poloniae - Acta Faunistica 9: 41-42. [In Polish with English Abstract and Summary].

GorCZYCA J. 1994. Mirid communities (Heteroptera, Miridae) of plant assemblages of Częstochowska Highland. Annals of the Upper Silesian Museum, Natural History 14: 33-68.

GoRCZYCA J. 2004. Lądowe pluskwiaki różnoskrzydłe Heteroptera. Pp. 192-234. In: BogDANOwiCz W., CHUDZICKA E., Pilipiuk I. \& SkiBińSKa E. (eds), Fauna of Poland. Characteristics and checklist of species. Vol. I. Annelida, Arthropoda pro parte, Insecta pro parte (Coleoptera, Hemiptera, Hymenoptera, Lepidoptera). Museum and Institute Zoology PAS, Warszawa, 509 pp.

GorCZYCA J. \& HerCZEK A. 1991. The mirids (Miridae, Heteroptera) of selected plant assemblages in the vicinities of Mielnik on the river Bug. Acta Biologica Silesiana 18 (35): 118-125. [In Polish with English Summary].

GorCZYCA J. \& WolSKi A. 2011. Plant bugs (Heteroptera: Miridae) of Poland. Catalogus faunae Poloniae, New Series 3. Natura optima dux Foundation, 172 pp.

HANUS K. \& LIS B. 2014. True-bugs (Hemiptera: Heteroptera) of selected meadow communities of the Nature 2000 area „Meadows in a vicinity of Kluczbork by the Stobrawa river” (Opole voivodship). Heteroptera Poloniae Acta Faunistica 8: 9-19. [In Polish with English Abstract]

HEBDA G. 2006. Heteropterans (Insecta: Heteroptera) on limestone quarries in the Chełm area (Opole Silesia). Pp. 8394. In: NowAK A., HebDa G. (eds), Biodiversity of quarries and pits. Opole Scientific Society, 3rd Department of Natural Sciences, Opole-Górażdże.

HebDA G. 2011. New data on the distribution of terrestrial true-bugs (Hemiptera: Heteroptera) in the Białowieża Primeval Forest. Heteroptera Poloniae - Acta Faunistica 3: 11-19. [In Polish with English Abstract]

HeBDA G. \& LIS B. 2007. Nowe stanowiska pluskwiaków różnoskrzydłych (Hemiptera: Heteroptera) w Górach Opawskich (Sudety Wschodnie). Pp. 189-207. In: LIS J. A., MAZuR M. A. (eds), Przyrodnicze wartości polskoczeskiego pogranicza jako wspólne dziedzictwo Unii Europejskiej. Centrum Studiów nad Bioróżnorodnością, Uniwersytet Opolski.

HEBDA G. \& RUTKOWSKI T. 2015. First data on the occurrence of terrestrial true-bugs (Hemiptera: Heteroptera) in Ujście Warty National Park. Entomological News 34 (1): 12-18. [In Polish with English Abstract and Summary].

HeRCZEK A. 1982. Miridae (Heteroptera) zespołów roślinnych okolic Dolistowa. Acta Biologica Silesiana 10: 22-29.

HERCZEK A. 1987. Zgrupowania tasznikowatych (Miridae, Heteroptera) wybranych zbiorowisk kserotermicznych okolic Pińczowa. Acta Biologica Silesiana 6: 130-148.

HerczeK A. \& NAKonieczny M. 1987. A note on mirids (Miridae, Heteroptera) in the vicinity of Kalisz Pomorski. Acta Biologica Silesiana 6: 99-107.

HRADIL K., KMENT P., BRYJA J., RohÁČOVÁ M., BAŇǍ̌ P. \& ĎURČOVÁ K. 2008. New and interesting records of true bugs (Heteroptera) from the Czech Republic and Slovakia IV. Klapalekiana 44: 165-206. 
KARL O. 1935. Ein Beitrag zur Hemipterenfauna Ostpommerns. Wanzen, Zikaden und Blattflöche. Dohrniana, Abhandlungen und Berichte der Pommerschen Naturforschenden Gesellschaft 14: 122-141.

Kerzhner I. A. \& Josifov M. 1999. Cimicomorpha II, Miridae. Pp. 1-577. In: Aukema B., Rieger Ch. (eds), Catalogue of the Heteroptera of the Palaearctic Region. Volume 3. The Netherlands Entomological Society, Wageningen.

KonDRACKI J. 2011. Geografia regionalna Polski. Wydawnictwo Naukowe PWN. Warszawa: 440 pp.

KoRCZ A. 2003. Heteroptera in diverse natural habitats of Słowiński National Park and the Rowokół Hill. Rozprawy Naukowe Instytutu Ochrony Roślin 13: 1-226. [In Polish with English Summary]

KożUCHOWSKI K. 2011. Klimat Polski - nowe spojrzenie, Wydawnictwo Naukowe PWN, Warszawa, 293 pp.

LeChOWSKi L. \& CMOluchowA A. 1996. Quantitative Structure of the Heteropters (Heteroptera) of the Projected Wieprzec Reservation near Zamość. Annales Universitatis Mariae Curie-Skłodowska, C, Biologia 49 (15): 205212. [In Polish with English Summary]

Lis B. \& DuBIEL G. 2013. Acetropis longirostris Put. and Oxycarenus pallens (H.-S.) - two species of true-bugs (Hemiptera: Heteroptera) new for the Polish fauna, with a checklist of species collected in a vicinity of Bystra in the Silesian Beskid. Heteroptera Poloniae - Acta Faunistica 7: 33-44. [In Polish with English Abstract]

LIS J. A. 1989. True-bugs (Insecta: Heteroptera) of the Silesian Upland. Annals of the Upper Silesian Museum in Bytom, Natural History 12: 5-60. [In Polish with English Abstract and Summary]

Lis J.A., Lis B. \& GorczycA J. 1995. Bugs (Heteroptera) of the middle basin of the Biebrza River Valley. Entomological news 14 (2): 85-93. [In Polish with English Abstract]

Lis J. A. \& LIS B. 1998. True-bugs of Śląsk Górny - an annotated checklist (Hemiptera: Heteroptera). Annals of the Upper Silesian Museum, Entomology 8-9: 107-146.

LIS J. A. \& ZIAJA D. J. 2009. Changes in distribution range of Tritomegas sexmaculatus (Rambur, 1839) (Hemiptera: Heteroptera: Cydnidae) in Poland as a possible effect of climate changes? Nature Journal (Opole Scientific Society) 42: 123-128. [In Polish with English Abstract]

LUKASHUK A. O. 2013. Taksonomicheskaja struktura naselenija nasekomyh na pojmennyh lugah Berezinskogo biosfernogo zapovednika. [Taxonomical structure of insects population on floodplain meadows of Berezinsky Biosphere Reserve]. In: PrishePA I. M., Kusmenko V. Y., LitVEnKova I. A., MERShVinski L. M., BobriK G. G., LESHKO A. A. (eds), Ecological culture and environmental protection: I Dorofeev reading. Materials of the International Scientific-practical Conference, Vitebsk, 21-22 November 2013. Vitebsk: VGU named P.M. Masherova, 178-180. [in Russian]

MATUSZCZYK J. \& TASZAKOWSKI A. 2017. Terrestrial true-bugs (Hemiptera: Heteroptera) of the Stary Groń massif (Silesian Beskid Mts.). Heteroptera Poloniae - Acta Faunistica 11: 65-71. [In Polish with English Abstract and Summary].

MENÉNDEZ R. 2007. How are insects responding to global warming. Tijdschrift voor Entomologie, 150: 355-365.

Musolin D. L. 2007. Insects in a warmer world: ecological, physiological and life-history responses of true bugs (Heteroptera) to climate change. Global Change Biology, 13: 1565-1585.

Nikolaeva A. M. \& RuChin A. B. 2016. Annotirovannyj spisok poluzhestkokrylyh nasekomyh (Insecta, Heteroptera) Mordovskogo Zapovednika (po materialam 2015 goda). [Annotaded list of true bugs (Insecta, Heteroptera) of Mordovski Reserve (on materials of 2015)]. Proceedings of Mordovia State Nature Reserve named after P.G. Smidovich, 16: 381-390. [in Russian]

NoGA P. \& LIS B. 2015. Results of faunistic studies on true-bugs (Hemiptera: Heteroptera) of selected meadow phytocoenoses of Przedmość (Opole voivodeship). Heteroptera Poloniae - Acta Faunistica 9: 51-79. [In Polish with English Abstract and Summary]

PiAseCKA J. 1960. Hemiptera - Heteroptera łąk nadleśnictwa Janów Lubelski. Annales Universitatis Mariae CurieSkłodowska. Sectio C. Biologia 15 (4): 89-109.

Polentz G. 1944. Beitrage zur Kenntnis der schlesischen Wanzen. Zeitschrift für Entomologie 19 (3): 7-14.

RABiTSCH W. 2008. The Times They Are A-Changin`: Driving forces of recent additions to the Heteroptera fauna of Austria. In: Grozeva S. \& Simov N. (eds), Advances in Heteroptera Research. Pensoft Publication, Sofia, 309-326.

REMANE R. \& GÜNTHER H. 2008. Acetropis stysi, a new species from Spain (Hemiptera: Heteroptera: Miridae). Acta Entomologica Musei Nationalis Pragae 48: 389-394.

RoHÁČOvÁ M. 2011. True Bugs (Heteroptera) of the Beskidian and Subbeskidian peaty habitats 1. Obidová Nature Monument. Acta Musei Beskidensis 3: 85-102. [In Czech with English Abstract]

Scholz M. F. R. 1931. Verzeichnis der Wanzen Schlesiens. Entomologischer Anzeiger. Spezialzeitschrift für entomologischen Handel, Verkehr und Literatur, Wien 11: 78-92, 99-102, 117-120.

Schumacher F. 1913. Weitere Beitrage zur Hemipteren-Fauna der Provinz Posen. Deutsche Entomologische Zeitschrift. Deutschen Entomologischen Gesellschaft 6: 670-680.

SiLFVERBERG H. 2012. Changes 2006-2010 in the list of Finnish insects. Entomologica Fennica 23: $18-41$.

SKÓRKA S. 1994. Land-bugs (Heteroptera) of the Puszcza Zielonka forest near Poznań. Acta Entomologica Silesiana 2 (1): 13-20.

SMRECZYŃSKI S. 1906. Zbiór pluskwiaków prof. Dra Stanisława Zaręcznego. Sprawozdanie Komisyi Fizyograficznej 40 (2): 1-26.

SMRECZYŃSKI S. 1908. Dodatek do spisu pluskiew św. p. prof. B. Kotuli. Sprawozdanie Komisyi Fizyograficznej 43: 69-79. 
SMRECZYŃSKI S. 1954. Materiały do fauny pluskwiaków (Hemiptera) Polski. Fragmenta Faunistica 7: 1-146; DOI: 10.3161/00159301FF1954.7.1.001

STEHLÍK J. L. 1988. New records of Heteroptera from Moravia. Acta Musei Moraviae, Scientiae Naturales, 73: 227-228.

STICHEL W. 1933. Illustrierte Bestimmungstabellen der deutschen Wanzen. Berlin-Hermsdorf. Verlag naturwissenschaftlicher Publikationen Dr. W. Stichel, 1925-1938. Berlin.

StiCHEL W. 1956. Illustrierte Bestimmungstabellen der Wanzen. II. Europa (Hemiptera-Heteroptera Europae). BerlinHermsdorf.

STICHEL W. 1960. Gotthold Kunows Wanzenfauna von Ost- und Westpreussen. Berlin, 80 pp.

STOBIECKI S. 1915. Wykaz pluskwiaków (Rhynchota) zebranych w Galicji zachodniej i środkowej. Sprawozdanie Komisyi Fizyograficznej 49: 1-96.

STRAWIŃSKI K. 1936. Badania nad fauną pluskwiaków drzew i krzewów w Polsce. Rozprawy i sprawozdania Instytutu Badawczego Lasów Państwowych 17: 1-216.

STRAWIŃSKI K. 1957. Analiza materiału Hemiptera-Heteroptera zebranego z łąkowych biotopów w okolicach Świętajna, Poj. Mazurskie. Annales Universitatis Mariae Curie-Skłodowska. Sectio C. Biologia 12 (4): 33-44.

STRAWIŃSKI K. 1963. Powiązania biocenotyczne owadów Hemiptera-Heteroptera z biotopami zadrzewionymi i niezadrzewionymi w okolicach Puław. Annales Universitatis Mariae Curie-Skłodowska, C. Biologia 18: 1-27.

STRAWIŃSKI K. 1965. Zestawienie zgrupowań gatunków Hemiptera-Heteroptera niezacienionych biotopów śródleśnych w nadleśnictwie Duninów koło Płocka. Annales Universitatis Mariae Curie-Skłodowska. Sectio C. Biologia 20 (1): 1-8.

STRAWINSKI K. 1966. The influence of some ecological habitat factors on Hemiptera-Heteroptera communities. Ekologia Polska, seria A 14 (13): 215-225.

ŠTYS P. 1973. The taxonomy of Acetropis longirostris Put. (Heteroptera, Miridae). Annotationes Zoologicae et Botanicae 86: 1-11.

ŠTYS P. 1974. Population explosion of Acetropis longirostris in Eastern Slovakia (Heteroptera, Miridae). Biologia (Bratislava) 29 (8): 667-670.

SZULCZEWSKI A. 1913. Beitrag zu einem Verzeichnis der Posener Rhynchoten (Hemiptera). Deutsche Entomologische Zeitschrift. Deutschen Entomologischen Gesellschaft 3: 307-314.

TAsZAKOWSKI A. \& GoRCZYCA J. 2018. Terrestrial true-bugs (Hemiptera: Heteroptera) of the Eastern Beskidy Mountains - origin of fauna. Monograph of the Upper Silesian Museum in Bytom 8 (in press). [In Polish with English Abstract and Summary]

TEnENBAum S. 1921. Pluskwiaki (Rhynchota) z Ordynacji Zamojskiej. Pamiętnik Fizyjograficzny 21, III: 1-72.

TROJAN P. 1989. Bug (Heteroptera) associations in the agricultural landscape of Great Poland. Ekologia Polska 37: 135-155.

Wachmann E., Melber A. \& DeCKert J. 2004. Wanzen. Band 2. Cimicomorpha. Microphysidae (Flechtenwanzen), Miridae (Weichwanzen). Die Tierwelt Deutschlands, 75 Teil, Goecke \& Evers, Keltern, 288 pp.

WAgner E. 1941. Beitrag zur Heteropterenfauna Pommerns. Dohrniana, Abhandlungen und Berichte der Pommerschen Naturforschenden Gesellschaft 20: 33-78.

WAGNER E. 1952. Blindwanzen oder Miriden. Die Tierwelt Deutschlands und der angrenzenden Meeresteile 41: 218 pp.

WAGNER E. \& WEBER H. H. 1964. Hémiptères Miridae. Faune de France 67: 591 pp.

WAGNER E. 1970. Die Miridae Hahn, 1831, des Mittelmeerraumes und der Makaronesischen Inseln (Hemiptera, Heteroptera). Teil 1. Entomologische Abhandlungen 37 (Supplementum): 1-484.

WALCZYK E. 2009. Materials to the knowledge of true bugs (Heteroptera) Miedzianka Hill nature reserve (ChęcińskoKielecki Landscape Park). Rocznik Świętokrzyski, B (Nauki Przyrodnicze) 30: 111-120. [In Polish with English Abstract and Summary]

\section{STRESZCZENIE}

\section{[Uwagi na temat występowania Acetropis Fieber, 1858 (Heteroptera: Miridae: Stenodemini) w Polsce]}

$\mathrm{Na}$ terenie Polski występują trzy gatunki z rodzaju Acetropis Fieber, 1858: A. carinata (Herrich-Schaeffer, 1841), A. gimmerthalii (Flor, 1860) i A. longirostris Puton, 1875. Wszystkie gatunki związane są pokarmowo z trawami (Poaceae). W pracy przedstawiono ilustrowany klucz do oznaczania wymienionych gatunków. Ze względu na częste błędy w identyfikacji przedstawicieli rodzaju Acetropis, zamieszczono ryciny prezentujące ich morfologię. Praca zawiera dane literaturowe, a także nowe stanowiska wszystkich gatunków na całym obszarze Polski, a także podsumowuje informacje dotyczące ich zasięgu występowania na terenie Palearktyki. Poprawne oznaczenie okazów A. longirostris pozwoliło stwierdzić, że ten ekspansywny gatunek dotarł do Polski znacznie wcześniej niż dotychczas sądzono. 